\title{
Targeting Nonsense: Optimization of 1,2,4-Oxadiazole TRIDs to Rescue CFTR Expression and Functionality in Cystic Fibrosis Cell Model Systems
}

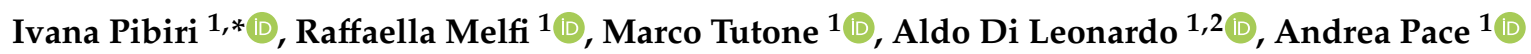 \\ and Laura Lentini ${ }^{1, *}$ \\ 1 Dipartimento di Scienze e Tecnologie Biologiche, Chimiche e Farmaceutiche (STEBICEF), Università degli \\ Studi di Palermo, Viale delle Scienze Ed. 16-17, 90128 Palermo, Italy; raffaella.melfi@unipa.it (R.M.); \\ marco.tutone@unipa.it (M.T.); aldo.dileonardo@unipa.it (A.D.L.); andrea.pace@unipa.it (A.P.) \\ 2 Centro di OncoBiologia Sperimentale (COBS), via San Lorenzo Colli, 90145 Palermo, Italy \\ * Correspondence: ivana.pibiri@unipa.it (I.P.); laura.lentini@unipa.it (L.L.); \\ Tel.: +39-091-238-97545 (I.P.); +39-091-238-97341 (L.L.)
}

Received: 13 July 2020; Accepted: 1 September 2020; Published: 3 September 2020

\begin{abstract}
Cystic fibrosis (CF) patients develop a severe form of the disease when the cystic fibrosis transmembrane conductance regulator (CFTR) gene is affected by nonsense mutations. Nonsense mutations are responsible for the presence of a premature termination codon (PTC) in the mRNA, creating a lack of functional protein. In this context, translational readthrough-inducing drugs (TRIDs) represent a promising approach to correct the basic defect caused by PTCs. By using computational optimization and biological screening, we identified three new small molecules showing high readthrough activity. The activity of these compounds has been verified by evaluating CFTR expression and functionality after treatment with the selected molecules in cells expressing nonsense-CFTR-mRNA. Additionally, the channel functionality was measured by the halide sensitive yellow fluorescent protein (YFP) quenching assay. All three of the new TRIDs displayed high readthrough activity and low toxicity and can be considered for further evaluation as a therapeutic approach toward the second major cause of $\mathrm{CF}$.
\end{abstract}

Keywords: premature termination codon; nonsense mutation; genetic disorder; translational readthrough inducing drugs; oxadiazoles

\section{Introduction}

Protein synthesis is a crucial process for life; therefore, gene mutations can seriously compromise the quality of life and even life expectancy.

A point mutation in the gene can result in a silent, missense, or nonsense mutation. In the fortunate case of a silent mutation, there are no effects on the amino acid sequence of the resulting protein. A missense mutation, which alters the primary structure, can cause protein malfunctioning due to incorrect folding or different conformations in the active site of a specific functional protein [1].

In the worst case, when a nonsense mutation is present in the gene producing a premature termination codon in the transcript, the protein production is compromised. A surveillance mechanism named NMD (nonsense-mediated decay) intervenes to destroy aberrant transcripts, and the small amount of leftover mRNA bearing the PTC will produce truncated polypeptides that, in turn, will be degraded as aberrant protein [2].

When a PTC occurs in the transcript, a basal readthrough partially restores protein synthesis to a very small extent, although this is too low to make an improvement in the disease phenotype [3]. 
If compared to basal readthrough, drug-induced readthrough allows for the restoration of protein synthesis to a wider extent [4]. Both basal and drug-induced readthrough of PTCs are known to occur by a misreading of the PTC by a near-cognate tRNA [5-8]. In particular, it has been suggested that a tRNA carrying tryptophan, cysteine, or arginine misreads the third base (A/G for tryptophan; A/U,C for cysteine) or the first base (U/C for arginine) of the UGA premature termination codon. The same kind of misreading could justify the insertion of glutamine, tyrosine, or lysine during the readthrough of the other two PTCs (UAG and UAA), as sketched in a genetic language translation roulette in Figure $1[3,8]$.

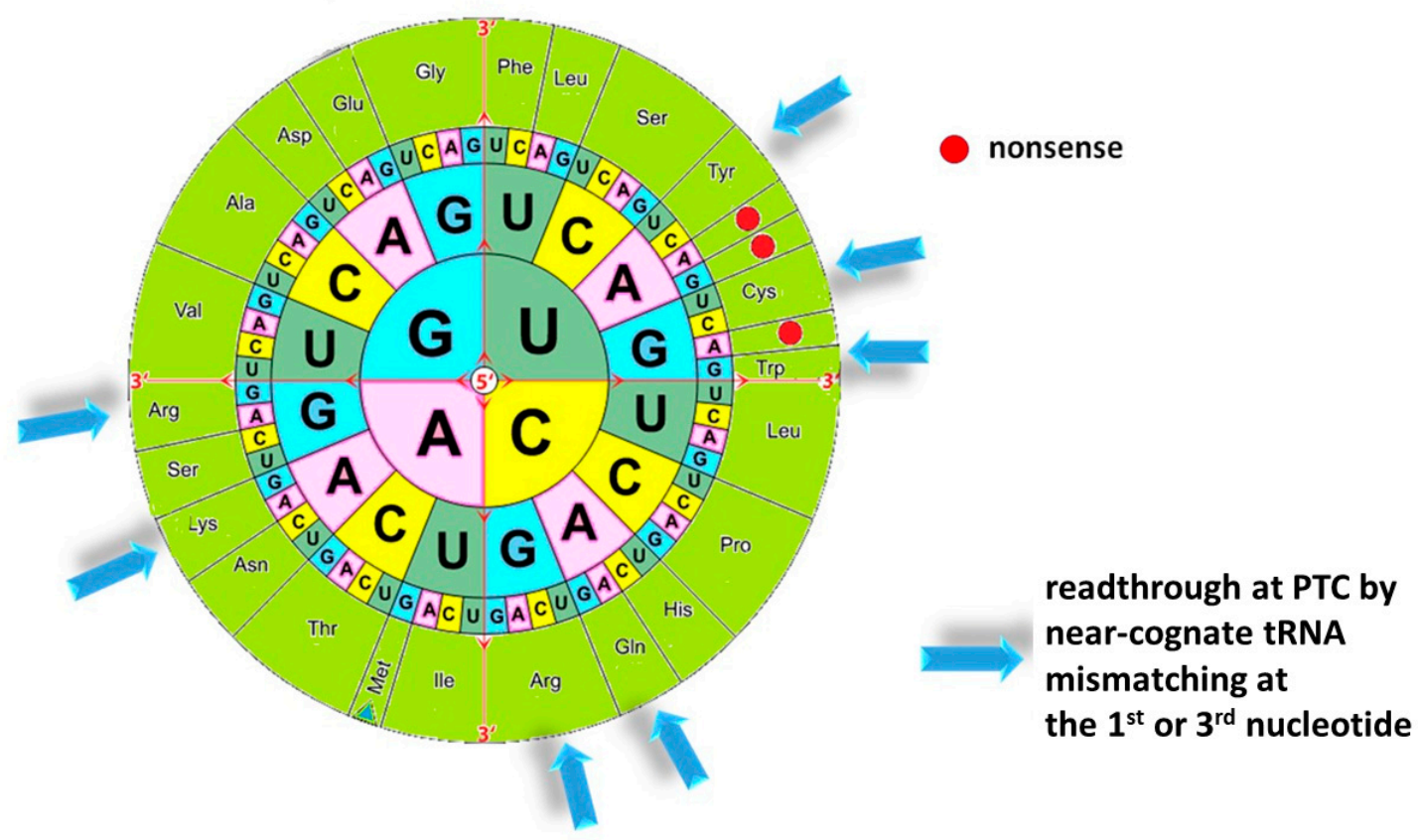

Figure 1. Codons language and most frequent misreadings for premature termination codon (PTC)'s readthrough.

The readthrough process depends on the kind of PTC, its location in the gene, and the surrounding mRNA sequence. Its efficiency is affected by the nucleotide immediately downstream of the PTC; moreover, the role of ancillary bases upstream of the PTC has recently been noted in the literature regarding drug-induced readthrough [7-9].

The amount of protein rescued by readthrough can be raised by NMD inhibition, as reported in many cases [10-14].

The production of a functional protein is guaranteed when the readthrough causes the insertion of the wild-type amino acid in the correspondence of the PTC. Alternatively, the readthrough can also skip the nonsense and produce the effect of a missense mutation, as widely discussed $[15,16]$.

Nonsense mutations are found in about $11 \%$ of genetic disorders such as cystic fibrosis (CF) [17], Duchenne muscular dystrophy (DMD) [18], spinal muscular atrophy [19,20], neurofibromatosis [21], retinitis pigmentosa [22-24], lysosomal storage disease [13,25,26], Rett syndrome [27], Shwachman-Diamond syndrome [28,29], and Usher's syndrome (USH) [30]. In this context and despite its limits, the translational readthrough of PTCs can represent a valuable pharmaceutical approach to target the specific genetic defect caused by nonsense mutations.

Among genetic disorders, cystic fibrosis $(\mathrm{CF})$ is not a rare disease as it involves more than 100,000 people worldwide and affects approximately 36,000 individuals in the European Union (EU), while 1000 new cases of CF are diagnosed each year in the US [31].

The cystic fibrosis transmembrane conductance regulator (CFTR) gene encodes for a channel protein, which is fundamental for cellular homeostasis. CFTR starts its biogenesis by co-translational 
insertion into the membrane of the endoplasmic reticulum and, by following the folding of the cytosolic domains, takes on its native fully folded compact structure. Then, CFTR is modified at the Golgi apparatus and delivered to the plasmatic membrane. It works as a cAMP- and phosphorylation-regulated chloride/bicarbonate channel [32]. Both its biogenesis and functional chloride secretion and hydration determine its overall activity and, thus, contribute to the fine modulation of the homeostasis of the epithelial surfaces [32].

About 2000 different mutations have been described as being involved in the onset of the disease [33], some of which are more common, such as the deletion of the triplet encoding for phenylalanine $508(\Delta \mathrm{F} 508)$ or the missense mutation, which substitutes glycine 551 with aspartic acid (G551D).

In addition to addressing the disease symptomatically, a personalized medicinal approach targeting the specific protein defect has also been used recently in many studies in the CF field [34-38].

Recently, a pharmacological treatment that combines three different drugs (elexacaftor/tezacaftor/ ivacaftor), which act synergistically, has been approved to overcome the $\triangle$ F508 CFTR defect. On the other hand, however, nonsense mutations, which recur in $10-15 \%$ of the CF cases worldwide, are still lacking an effective pharmacological approach.

Despite the significant efforts devoted to finding a cure for $\mathrm{CF}$, there is no current therapy for the nonsense mutations of the CFTR gene that cause the lack of CFTR protein and are responsible for a more severe form of the disease (Figure 2A,B) [39].

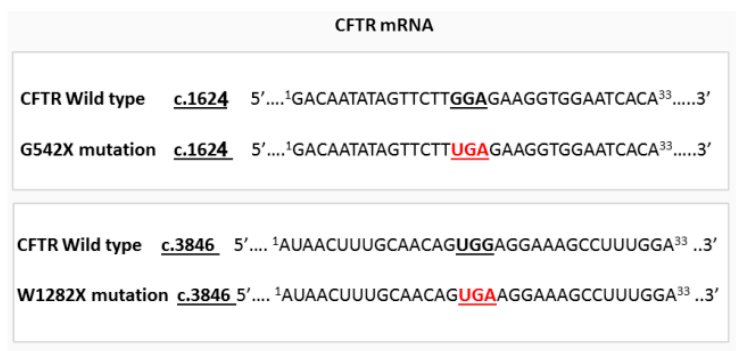

(A)

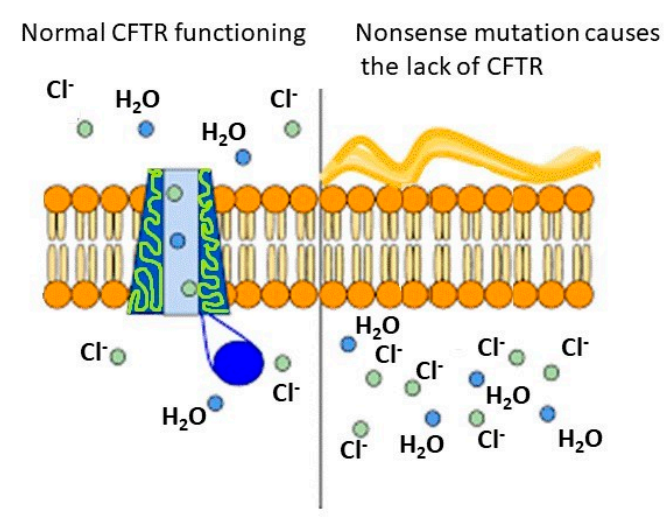

(B)

Figure 2. Illustrations of cystic fibrosis transmembrane conductance regulator (CFTR) nonsense mutations and their effect. (A) CFTR mRNA sequence of the stop codon G542X and W1282X (in red the PTC UGA codons). (B) CFTR localization and effect of the nonsense mutation on the CFTR gene, impairing cell homeostasis and causing the accumulation of mucus and the following infection.

A potential therapeutic approach is represented by the development of drugs inducing the readthrough of nonsense mutations. By promoting a selective bypass of the PTC, the readthrough 
approach would restore the expression of the CFTR protein and, once functionality is rescued to a sufficient extent, improve cell homeostasis.

The first drugs tested as translational readthrough-inducing drugs (TRIDs) were aminoglycosides (e.g., gentamicin, tobramycin, paromomycin, geneticin; see Figure 3), which have been shown to suppress the normal proof-reading function of the ribosome [40,41]. These drugs, which were already known for their antibiotic activity, induce the readthrough of the PTCs continuing the translation process [42]. Unfortunately, the chronic use of high dosages of aminoglycosides is associated with severe side-effects such as renal, auditory, and vestibular toxicities [43], which is what inhibited their pharmaceutical implementation. Nevertheless, a new aminoglycoside, showing potential activity as a TRID and reduced toxicity, has been tested in healthy subjects and is currently proceeding further in clinical trials [44].<smiles>CNC1C(O)C(OC2C(N)CCC(N)C2OC2OC(C(C)O)C(O)C(O)C2N)OCC1(C)O</smiles>

Geneticin<smiles>NCC1OC(OC2C(CO)OC(OC3C(O)C(N)CC(N)C3OC3OC(CO)C(O)C(O)C3N)C2O)C(N)C(O)C1O</smiles>

Paronomycin<smiles>CC(N)C1OC(OC2C(O)C(N)CC(N)C2OC2OC(C(C)O)C(O)C(O)C2N)C(O)C1O</smiles>

$$
\mathrm{OH}_{\mathrm{OH}}^{\mathrm{O}}
$$

Amlexanox<smiles>CC(C)c1ccc2oc3nc(N)c(C(=O)O)cc3c(=O)c2c1</smiles><smiles>NCC1OC(OC2C(N)CC(N)C(OC3OC(CO)C(O)C(N)C3O)C2O)C(N)CC1O</smiles>

Tobramycin<smiles>CNC(C)C1CCC(N)C(OC2C(N)CC(N)C(OC3OCC(C)(O)C(NC)C3O)C2O)O1</smiles>

Gentamicin<smiles>Nc1ncnc(NC(O)OC(O)CO)c1[N+](=O)[O-]</smiles>

Clitocine<smiles>CN(CC(=O)O)NC(=O)C[C@@H](N)C[C@@H](O)CN</smiles>

(+) negamycin

Figure 3. Different structures of proposed translational readthrough-inducing drugs (TRIDs). 
To overcome the aminoglycoside toxicity, different molecules such as (+)-negamicine [45], amlexanox [25], clitocine [46], and PTC124 (also known as ataluren) [47] (Figure 3) have been proposed as readthrough promoters. Among these, ataluren was able to promote the readthrough of PTCs, particularly UGA, without affecting the normal termination codons [47], thus being a good candidate for developing a therapy for nonsense mutations [48].

Phase I and II clinical trials, including healthy subjects and CF and Duchenne muscular dystrophy (DMD) patients, have evaluated the long-term safety of ataluren.

Trials showed improvement of some markers of CFTR function in CF patients; however, in a new phase III trial, sweat chloride levels and the nasal potential difference were not improved [49]. Due to conflicting results, the phase III clinical study of PTC124 was suspended in April 2017 for CF patients, while the drug has been registered with the regulatory authorities and is currently in use for DMD patients $[49,50]$. Specifically, during the trial with CF patients, reports have shown that there is a competition between ataluren and tobramycin (which interacts at the level of the ribosome) when administered simultaneously [49].

Our previous studies on ataluren and its analogs aimed to look for alternative molecules and to understand the effective biological target and mechanism of action of TRIDs [9,10,51-54].

We hypothesized that ataluren could interact differently with the PTCs, depending on their localization in the CFTR gene (e.g., G542X, R1162X, W1282X) and on the genetic context [9].

Our research has focused on oxadiazoles, as they are widely recognized as lead compounds in medicinal chemistry [55-59], particularly as bioisosteric replacements for ester and amide functionalities.

The flaws in the clinical trials for ataluren, as well as the discrete toxicity evidenced in the MTT test (see Figure S1) for our recently reported lead compound NV2445 [54], pushed us to find new alternative leads.

By performing an in-silico optimization of the lead molecule NV2445 [54] using public and "in-house" compound libraries, we designed and synthesized three small molecules containing a 1,2,4-oxadiazole as the heterocyclic core and evaluated their efficacy as TRIDs.

The preliminary biological screening was performed by using the firefly luciferase reporter; the activity was confirmed by further assays evaluating the efficacy in promoting the production of a functional CFTR protein in cells engineered to express the nonsense CFTR ${ }^{\mathrm{G} 542 \mathrm{X}}$ or CFTR ${ }^{\mathrm{W} 1282 \mathrm{X}}$ mRNA. Additional tests were conducted in vitro to evaluate the toxicity of the synthesized molecules.

\section{Results and Discussion}

\subsection{Design and Synthesis}

The 3D-QSAR pharmacophore modeling was carried out based on our previous results [54], which allowed the identification of a validated pharmacophore model. This model was used as a query to screen public and "in-house" compound libraries. From the top 5\% of retrieved hits, we selected three synthetically accessible 1,2,4-oxadiazoles (Figure 4).<smiles>CC(=O)Nc1noc(C)n1</smiles>

NV848<smiles>CCOC(=O)c1noc(-c2ccccc2)n1</smiles>

NV930<smiles>CN(C)OCCN(C)S(=O)(=O)c1c(F)c(F)c(F)c(F)c1-c1nc(NC(=O)c2c(F)c(F)c(F)c(F)c2F)no1</smiles>

NV914

Figure 4. 1,2,4-oxadiazoles selected structures. 
Interestingly, despite the common oxadiazole core, the suggested structures presented significant differences with respect to ataluren in terms of the lack of aryl substituents (NV848), the lack of fluorine and acidic moieties (NV848 and NV930), and the maximized fluorine content (NV914).

The synthesis and crystal structure of 3-acetylamino-5-methyl-1,2,4-oxadiazole, NV848, has been previously reported in the literature [60-62].

Ethyl 5-phenyl-1,2,4-oxadiazole-3-carboxylate (NV930) was prepared by the classic amidoxime route, as illustrated in Scheme 1.<smiles>CCOC(=O)/C(N)=N/O</smiles>

1<smiles>O=C(Cl)c1ccccc1</smiles>

Scheme 1. Synthesis of NV930.<smiles>CCOC(=O)c1noc(-c2ccccc2)n1</smiles>

NV930

2,3,4,5,6-Pentafluoro-N-(5-(perfluorophenyl)-1,2,4-oxadiazol-3-yl)benzamide (NV914) was prepared by acylation of the amine 2 [60-62] with perfluorobenzoyl chloride, as reported in Scheme 2.<smiles>Nc1noc(-c2c(F)c(F)c(F)c(F)c2F)n1</smiles>

2<smiles>O=C(Cl)c1c(F)c(F)c(F)c(F)c1F</smiles><smiles>CC(C)CC1CCCCC1C</smiles><smiles>N#Cc1c(F)c(F)c(F)c(F)c1-c1nc(NC(=O)c2c(F)c(F)c(F)c(F)c2F)no1</smiles>

NV914

Scheme 2. Synthesis of NV914.

All the synthesized compounds were purified by preparative flash chromatography and crystallization, analyzed by spectroscopic techniques, and displayed an appropriate purity grade for the biological assays.

\subsection{Testing Cell Proliferation and Viability}

Before testing the activity of the compounds as readthrough promoters, we tested their toxicity. Cell viability was assessed by the MTT assay after 24 and 72 h of exposition to NV848, NV91, and NV930. The assay showed that cell viability was already affected after $24 \mathrm{~h}$ of treatment with either PTC124 $(48 \mu \mathrm{M})$ or NV2445 $(48 \mu \mathrm{M})$, used as control. In contrast, NV848, NV914, and NV930 molecules did not show altered cell viability or proliferation (Figure S1) at the same time and concentration points. A partial cytotoxic effect was observed at $72 \mathrm{~h}$, especially after the addition of NV930 at the doses of 24 and $48 \mu \mathrm{M}$.

\subsection{Experimental Screening of the Readthrough Activity by Luciferase Assays, Immunofluorescence, and Western Blot Analyses}

To ascertain the efficacy of the newly synthesized small molecules in promoting the readthrough of premature termination codons, we used the FLuc cell-based assay $[52,53]$. Although it is not usually reliable as a quantitative assessment, this screening is easy and useful to find potential readthrough promoters. HeLa cells were transiently transfected with the plasmids pFLuc-WT (positive control) and pFLuc-opal (UGA stop mutation) [63]. After $24 \mathrm{~h}$, the new molecules were added to the cells and, finally, $48 \mathrm{~h}$ after the transfection, FLuc gene expression was measured by luminescence. 
HeLa cells transfected with the pFluc-WT plasmid were used as a positive control of the experiment. These cells showed high levels of luciferase activity (about $5 \times 10^{6}$ activity/relative luminescence units (RLU)). On the other hand, untreated pFluc-opal transfected HeLa cells did not show any activity (negative control). However, when pFluc-opal cells were treated with PTC124 and the three different analogs, we observed a significant increase of luciferase activity in comparison to untreated cells (Figure 5).

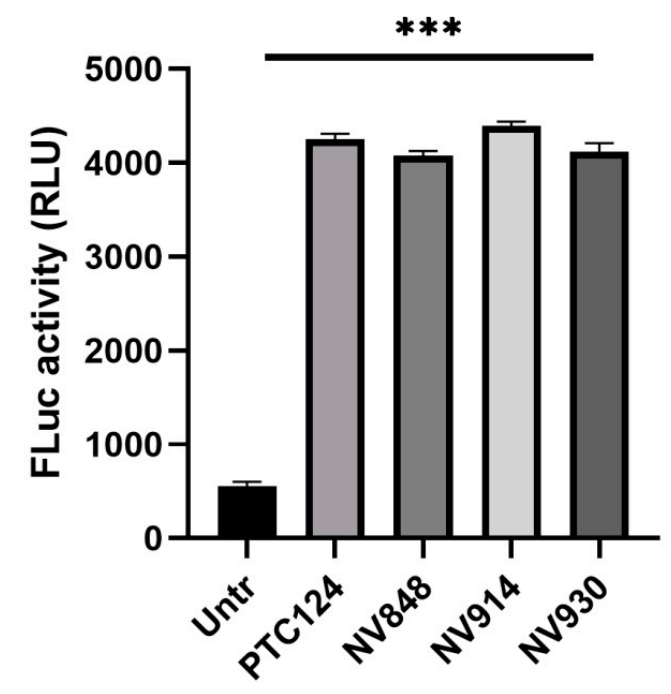

Figure 5. The newly synthesized molecules show readthrough activity in the FLuc cell model system. Histogram shows luciferase (FLuc) activity (RLU) after $24 \mathrm{~h}$ of exposition to PTC124, NV848, NV930, and NV914 (all at the concentration of $12 \mu \mathrm{M}$ ) in HeLa FLuc-opal transfected cells. Data were analyzed by GraphPad Prism 6 software and expressed as mean values \pm standard error of the mean (SEM; $n=3$ ). Symbol ${ }^{*}$ ) represents the statistical significance of data regarding PTC124, NV848, NV914, and NV930 versus Untr: ${ }^{* * *}, p<0.001$ (ANOVA with Dunnett's posthoc test).

The readthrough activity on the CFTR mRNA was studied in Fisher rat thyroid (FRT) cells. FRT cells do not express endogenous CFRT and other endogenous cAMP-regulated $\mathrm{Cl}^{-}$channels. The cells were transfected with a vector harboring the full-length CFTR cDNA (pTracer-CFTR) [64]. The vector harbored either a wild-type (WT) or a mutated CFTR cDNA in which we previously introduced one of the two stop mutations, G542X or W1282X, by site-directed mutagenesis [54].

To evaluate the readthrough activity of the three NV molecules, FRT cells transfected with the mutated cDNA were treated for $24 \mathrm{~h}$ with NV848, NV914, NV930, or PTC124 (positive control) at a $12 \mu \mathrm{M}$ concentration, chosen for better comparison to ataluren's reported activity [51]. The expression of the human CFTR-WT and the rescued CFTR (from CFTR ${ }^{\mathrm{G} 542 \mathrm{X}}$ or CFTR $^{\mathrm{W} 1282 \mathrm{X}}$ ) were detected by immunofluorescence and Western blot analyses.

Dose-response activity was tested only on FRT CFTR ${ }^{\mathrm{W} 1282 \mathrm{X}}$, and the maximum readthrough activity was recorded at $24 \mu \mathrm{M}$ for NV848 and NV930 (see Figure S2B,D). For NV914, the highest activity was recorded at $48 \mu \mathrm{M}$, with a very small increase with respect to activity at $24 \mu \mathrm{M}$ (see Figure S2C). The experiments were performed in duplicate and allowed us to obtain a preliminary estimate of the EC50 in the range 6-16 $\mu \mathrm{M}$ (see Table S1), although further tests are needed to define the new TRIDs' efficacy, especially for different mutations.

Immunofluorescence microscopy images allowed us to visualize CFTR localization at the cell membrane, in particular when the CFTR ${ }^{\mathrm{G} 542 \mathrm{X}}$ FRT cells were exposed to NV848 and NV930, suggesting the occurrence of translational readthrough after the treatments (Figure 6). On the other hand, in CFTR ${ }^{W 1282 X}$ FRT cells, the expression of the CFTR protein was significantly evident after treatment with NV914 and NV930, as shown by immunofluorescence (Figure 7). Similar results were detected and quantified by Western blot analyses (Figure 8A,B and Figure S3A,B). 


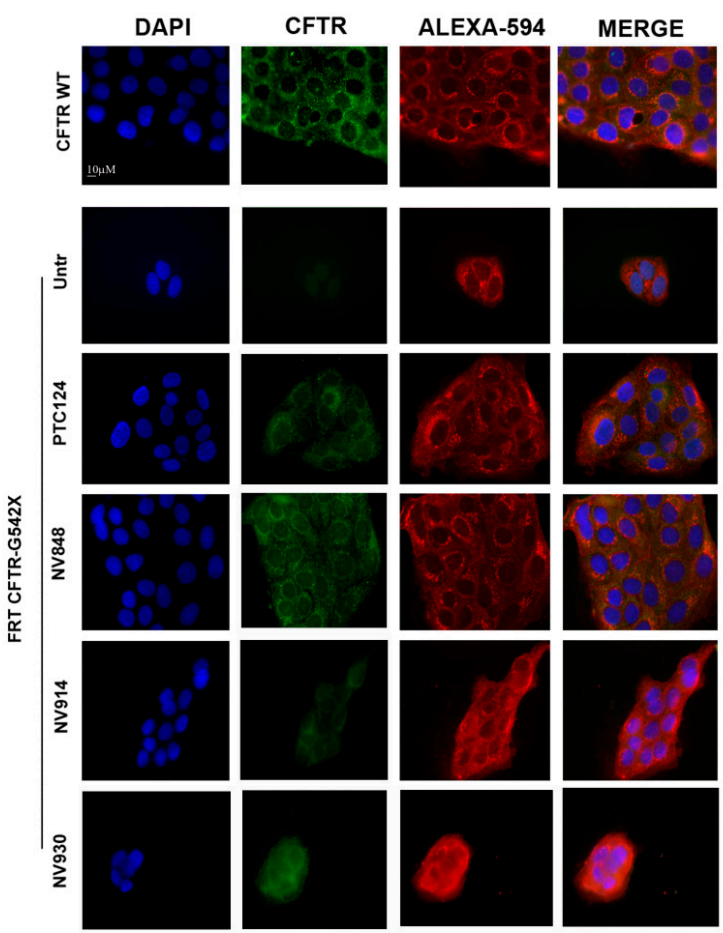

Figure 6. Immunofluorescence analysis of the full-length CFTR protein in wild-type (CFTR-WT) and CFTR $^{\text {G542X }}$ Fisher rat thyroid (FRT) cells, untreated (Untr) or treated with $12 \mu \mathrm{M}$ PTC124, NV848, NV930, or NV914 for $24 \mathrm{~h}$. CFTR protein was revealed by a specific antibody (ab570-green). Nuclei (blue) were DAPI (4',6-diamidino-2-phenylindole)-stained and the cellular membrane was stained by wheat germ agglutinin (WGA)-Alexa 594 (red).

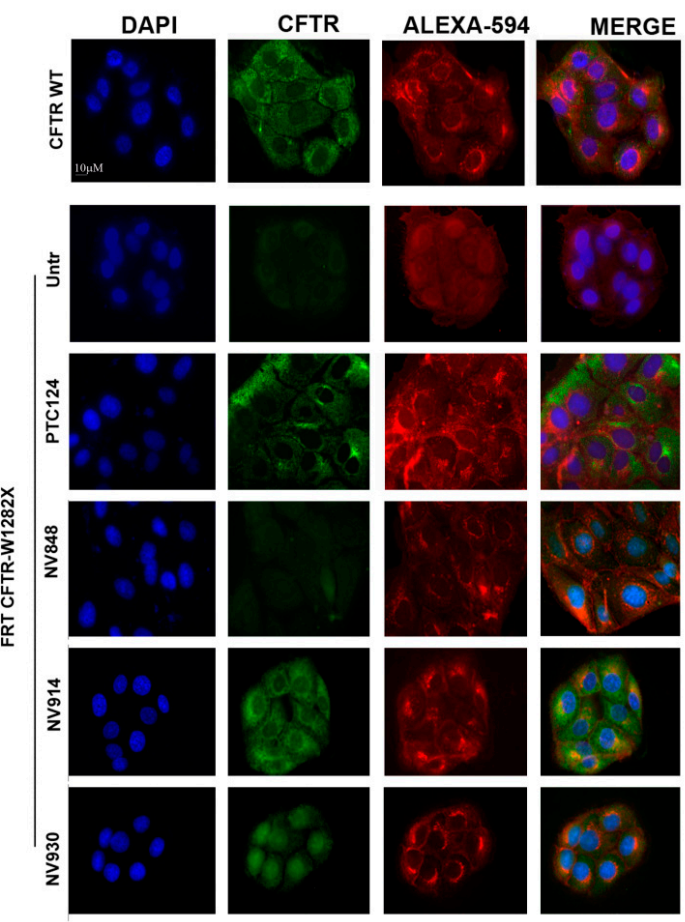

Figure 7. Immunofluorescence analysis of the full-length CFTR protein in wild-type (CFTR-WT) and CFTR $^{\text {W1282X }}$ FRT cells, untreated (Untr) or treated with $12 \mu$ M PTC124, NV848, NV930, or NV914 for $24 \mathrm{~h}$. CFTR protein was revealed by a specific antibody (ab570-green). Nuclei (blue) were DAPI-stained and the cellular membrane was stained by WGA-Alexa 594 (red). 

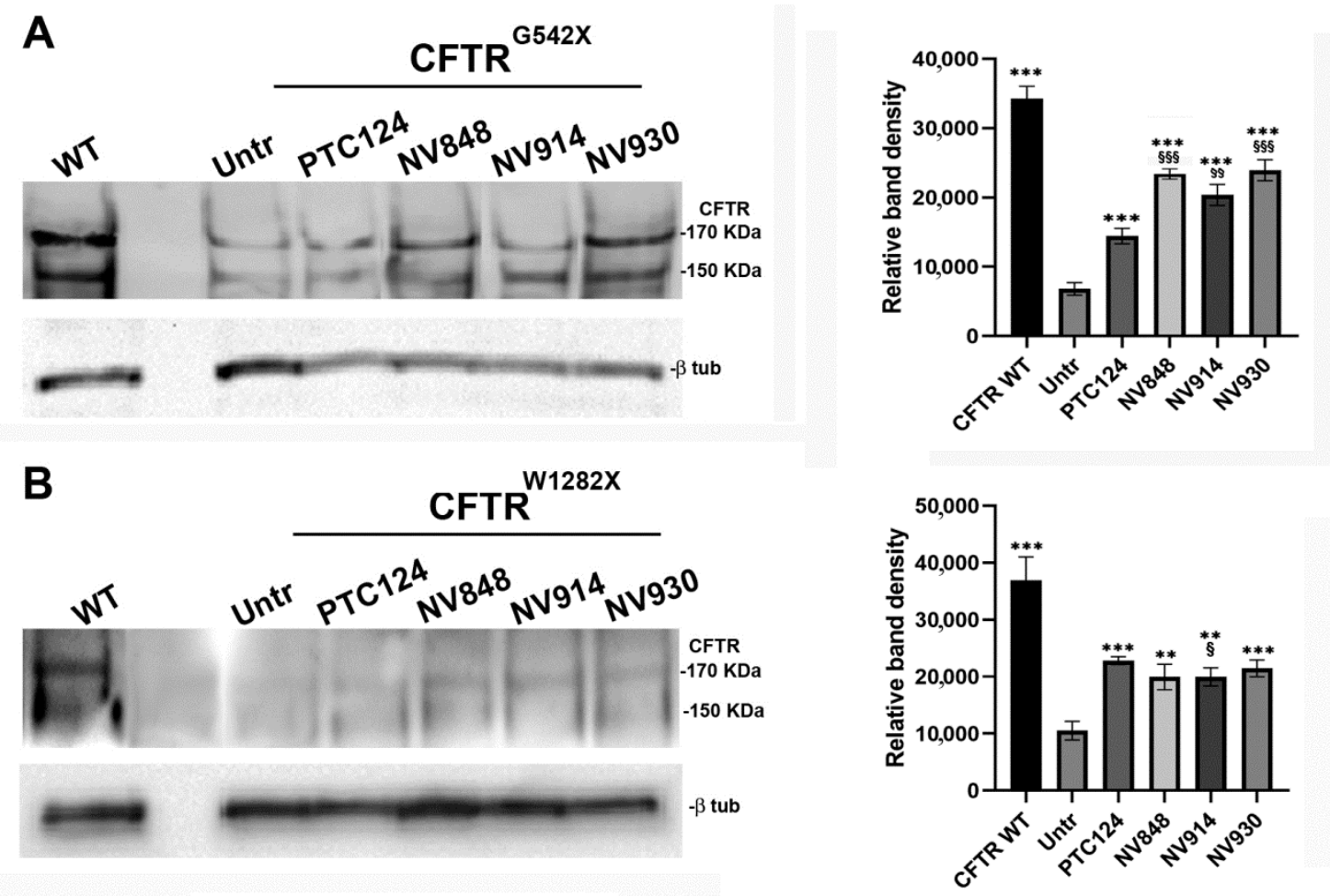

Figure 8. Western blot analysis of the CFTR protein in wild-type (WT) CFTR, and CFTRG542X (A) and $\mathrm{CFTR}^{\mathrm{W} 1282 \mathrm{X}}$ (B) FRT cells, untreated (Untr) or treated with $12 \mu \mathrm{M}$ PTC124 (positive control), NV848, NV930, or NV914 for 24 h; $\beta$-tubulin was used as control for the protein loading. The graphs show the quantification of the gel bands by ImageJ software. The experiment was performed in triplicate and data were normalized by $\beta$-tubulin expression, analyzed by GraphPad Prism 6 software. Data are expressed as mean values \pm standard error of the mean (SEM). Symbols (* and §) represent the statistical significance of NV848, NV914, and NV930 versus Untr $\left(^{*}\right)$ and versus PTC124 (§). two symbols, $p<0.01$; three symbols, $p<0.001$ (Student's $t$-test and ANOVA with Dunnett's posthoc test).

\subsection{Testing Functionality of the Recovered CFTR}

While the NMD pathway affects the amount of recovered protein, the variability of tRNA insertion plays a role in the quality of the protein produced by readthrough. In this context, besides measuring the effective protein production by quantitative methods, it is fundamental to prove protein functionality after readthrough.

For this purpose, molecular and functional analyses have been conducted by halide-sensitive YFP assay to evaluate the functionality of the CFTR channel produced in FRT cells after treatment with NV848, NV914, and NV930.

The assay is based on the sensibility of the YFP protein to the $\mathrm{I}^{-}$ion. In fact, iodide anions induce the quenching of YFP fluorescence (Figure 9A), thus evidencing the channel activity [65].

To evaluate the activity of the CFTR channel, CFTR $\mathrm{G}^{42 \mathrm{X}}$ and CFTR ${ }^{\mathrm{W} 1282 \mathrm{X}}$ FRT cells were treated for $24 \mathrm{~h}$ with either one of the NV848, NV914, or NV930 compounds. After $24 \mathrm{~h}$, cells were prestimulated with forskolin to activate the channel and observed by microscopy before and after the addition of NaI. Treated CFTR ${ }^{\mathrm{G} 542 \mathrm{X}}$ and $\mathrm{CFTR}^{\mathrm{W} 1282 \mathrm{X}}$, as well as WT-CFTR, FRT cells showed a significant quenching of the YFP fluorescence after the addition of iodide (Figure 9B,C), thus proving the channel functionality. Interestingly, the response to the YFP assay was different based on the stop codon undergoing the readthrough. In fact, CFTR G542X FRT cells clearly showed a YFP fluorescence quenching when treated with NV848, NV914, or NV930 (Figure 9C, left) while CFTR ${ }^{\mathrm{W} 1282 X}$ FRT cells showed quenching of the YFP fluorescence when specially treated with NV930 (Figure 9C, right). The same experiments were performed to measure the YFP fluorescence quenching after treatment with the three molecules in a 
fluorescent microplate reader and data are illustrated in Figure 9D as the percentage of fluorescent cells before $(-)$ and after $(+)$ the addition of $\mathrm{NaI}$.

A

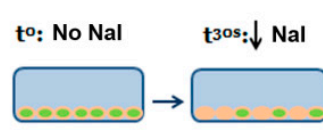

FSK pre-stimulation

C
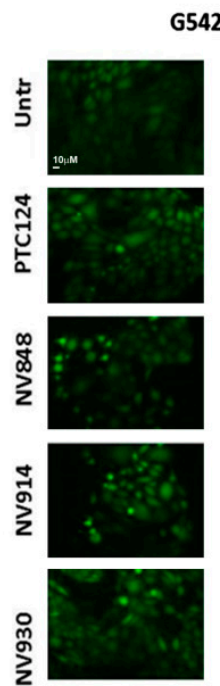

$42 X$
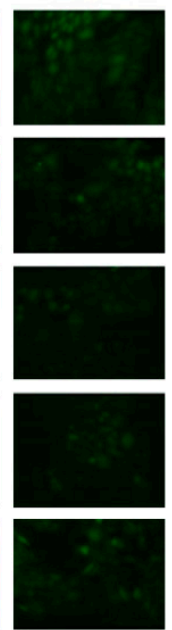
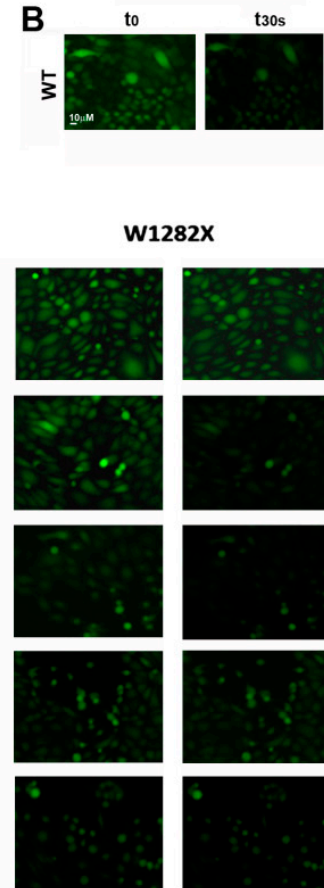

$1282 X$
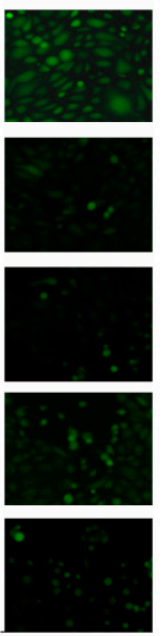

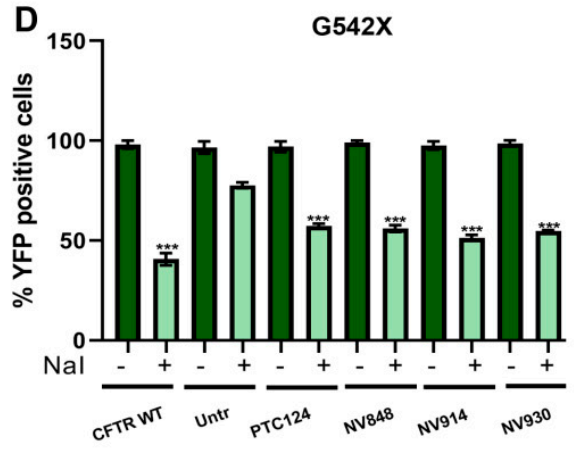

W1282X

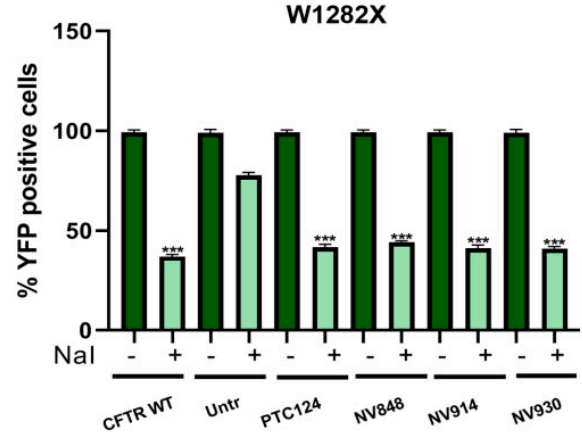

Figure 9. CFTR functionality in FRT cells measured by the yellow fluorescent protein (YFP) assay (pink: cells, green: YFP protein expression, blue: multiwell), (A) in YFP-CFTR ${ }^{\mathrm{WT}}$ FRT, and (B) $\mathrm{CFTR}^{\mathrm{G} 542 \mathrm{X}}$ and $\mathrm{CFTR}^{\mathrm{W} 1282 \mathrm{X}}$ FRT cells, untreated or treated with $12 \mu \mathrm{M}$ PTC124, NV848, NV914, or NV930 for $24 \mathrm{~h}(\mathrm{C})$. Cells were prestimulated with $20 \mu \mathrm{M}$ forskolin for $20 \mathrm{~min}$. The experiment was performed in triplicate. Images were taken before $\left(\mathrm{t}^{0}\right)$ and after $\left(\mathrm{t}^{30 \mathrm{~s}}\right)$ the addition of NaI. Percentages of YFP-positive cells before (- dark green bars) and after NaI addition (+ light green bars); data were analyzed by GraphPad $(n=3)$ and expressed as mean values \pm standard error of the mean (SEM) (D). Data were analyzed comparing treated FRT cells versus untreated FRT cells by GraphPad Prism 6 software $(n=3) .{ }^{* * *}, p<0.001$ (ANOVA with Dunnett's posthoc test).

\section{Materials and Methods}

\subsection{D-QSAR Pharmacophore Modeling and Virtual Screening}

The procedure has been reported in the literature [54,66-70].

\subsection{Chemistry}

All reagents and solvents were purchased from commercial sources. All synthesized compounds were first purified by silica flash chromatography and analyzed by IR, NMR, and HPLC/MS, assessing a purity grade ( $>95 \%)$. Melting points were determined by Kofler. ${ }^{1} \mathrm{H}$ NMR and ${ }^{13} \mathrm{C}$ NMR spectra were registered on a Bruker 300 Avance $(300 \mathrm{MHz})$ spectrometer, with TMS as an internal standard. IR spectra were recorded by a Shimadzu FTIR-8300 instrument (Shimadzu Corporation, Kyoto, Japan). Chromatography for purification of the samples was realized by flash silica gel (Merck, $0.040-0.063 \mathrm{~mm}$ ) and mixtures of petroleum ether (fraction boiling at $40-60^{\circ} \mathrm{C}$ ) and ethyl acetate as eluents. HRMS spectra were recorded by analyzing a $10 \mathrm{ppm}$ solution of each sample in a 6540 UHD Accurate-Mass Q-TOF LC/MS (Agilent Technologies, Inc., Santa Clara, CA, USA) equipped with a Dual AJS ESI source. 


\subsubsection{Synthesis of NV848 (N-(5-methyl-1,2,4-oxadiazol-3-yl)acetamide)}

The precursor 3-amino-5-methyl-1,2,4-oxadiazole was prepared as follows: $9.5 \mathrm{~g}(0.22 \mathrm{mmol})$ of cyanamide (previously purified with diethyl ether) was added to $1.47 \mathrm{~g}(0.22 \mathrm{mmol})$ of hydroxylamine hydrochloride solubilized in $\mathrm{EtOH}$ absolute. The reaction was refluxed for $8 \mathrm{~h}$. After this time, the solvent was removed under vacuum, and $30 \mathrm{~g}(0.31 \mathrm{~mol})$ of potassium acetate and $50 \mathrm{~mL}$ of acetic anhydride $(0.53 \mathrm{~mol})$ were added in three portions to the product, cooling the bottom flask with an ice bath. Then, the white solution was refluxed for $30 \mathrm{~min}$. After cooling, the reaction was decomposed with $300 \mathrm{~mL}$ of ice and water. The solution was alkalinized with $\mathrm{NaOH}(45 \mathrm{~g})$ and maintained at $80^{\circ} \mathrm{C}$ (bain-marie) for $45 \mathrm{~min}$. In the end, the reaction was extracted with diethyl ether $(6 \times 100 \mathrm{~mL})$.

Reaction yield $36 \%$, MP $119-121^{\circ} \mathrm{C}$. IR $\left(\mathrm{cm}^{-1}\right)$ : 3379, 3316, 3183. ${ }^{1} \mathrm{H}$ NMR (DMSO- $\left.d_{6}\right): 2.43(\mathrm{~s}, 3 \mathrm{H})$, $6.16(\mathrm{~s}, 2 \mathrm{H})$.

Additionally, $600 \mathrm{mg}$ of 3-amino-5-methyl-1,2,4-oxadiazole was solubilized into $1 \mathrm{~mL}$ of pyridine and $3 \mathrm{~mL}$ of acetic anhydride. The reaction was allowed to sit at room temperature overnight. After this time, the reaction was treated with water and extracted with ethyl acetate. The product was purified by chromatography.

NV848: Reaction yield 50\%, MP 162-163 ${ }^{\circ} \mathrm{C}$. IR $\left(\mathrm{cm}^{-1}\right)$ : 3254, 3205, 3120, 1695. ${ }^{1} \mathrm{H}$ NMR (DMSO-d6) $\delta(\mathrm{ppm}): 2.15(\mathrm{~s}, 3 \mathrm{H}), 2.60(\mathrm{~s}, 3 \mathrm{H}), 10.86(\mathrm{~s}, 1 \mathrm{H})$.

\subsubsection{Synthesis of NV930 (ethyl 5-phenyl-1,2,4-oxadiazole-3-carboxylate)}

NV930 was prepared by the classic amidoxime route: The amidoxime $\mathbf{1}(0.3 \mathrm{~g})$ [71] in toluene $(50 \mathrm{~mL})$ was placed in a $250 \mathrm{~mL}$ round-bottomed flask. After the addition of 1.2 eq. of benzoyl chloride and 1.2 eq. of pyridine, the reaction mixture was refluxed for $6-8 \mathrm{~h}$, monitoring the consumption of starting material by TLC. The solvent was removed under reduced pressure, followed by water addition and extraction with ethyl acetate. The extracted reaction mixture was chromatographed on silica gel, using eluent mixtures of petroleum ether and ethyl acetate. The obtained sample of the oxadiazole NV930 was further purified by crystallization in ethanol.

NV930: Reaction yield 80\%, MP 50-52 ${ }^{\circ} \mathrm{C}$, from ethanol. ${ }^{1} \mathrm{H}$ NMR $\left(300 \mathrm{MHz}, \mathrm{CDCl}_{3}\right) \delta(\mathrm{ppm})$ : $8.22(\mathrm{~d}, J=7.2 \mathrm{~Hz}, 2 \mathrm{H}), 7.64(\mathrm{t}, J=7.4 \mathrm{~Hz}, 1 \mathrm{H}), 7.55(\mathrm{t}, J=7.4 \mathrm{~Hz}, 2 \mathrm{H}), 4.55(\mathrm{q}, J=7.1 \mathrm{~Hz}, 2 \mathrm{H})$, $1.47(\mathrm{t}, J=7.1 \mathrm{~Hz}, 3 \mathrm{H})$. FT-IR $\left(\mathrm{cm}^{-1}\right), 1720$. HRMS for $\mathrm{C}_{11} \mathrm{H}_{10} \mathrm{~N}_{2} \mathrm{O}_{3}$ found $219.0699[\mathrm{M}+\mathrm{H}]^{+}$(Calcd. 219.0691).

3.2.3. Synthesis of NV914 (2,3,4,5,6-pentafluoro-N-(5-(perfluorophenyl)-1,2,4oxadiazol-3-yl)benzamide)

NV914 was prepared by acylation with perfluorobenzoyl chloride of the amine 2 [72-74].

1.2 eq. of perfluorobenzoyl chloride and 1.2 eq. of pyridine were added to 1.0 eq of the amine 2 dissolved in toluene, and the reaction mixture was refluxed for $4 \mathrm{~h}$, monitoring the consumption of the starting material by TLC. Solvent was removed under reduced pressure followed by water addition and extraction with ethyl acetate. The extracted reaction mixture was chromatographed on silica gel using eluent mixtures of petroleum ether and ethyl acetate. The sample was further purified by crystallization in ethanol.

NV914: Reaction yield 90\%, MP 208-210 ${ }^{\circ} \mathrm{C}$, from ethanol. ${ }^{1} \mathrm{H} \mathrm{NMR}\left(300 \mathrm{MHz}, \mathrm{CDCl}_{3}\right) \delta(\mathrm{ppm})$ : $9.09(\mathrm{~s}, 1 \mathrm{H})$, FT-IR $\left(\mathrm{cm}^{-1}\right), 3290,3180,1750$. HRMS for $\mathrm{C}_{15} \mathrm{HF}_{10} \mathrm{~N}_{3} \mathrm{O}_{2}$ found $445.9917[\mathrm{M}+\mathrm{H}]^{+}$ (Calcd. 445.9909).

\subsection{Cell Culture Conditions and Transfection of Reporter Plasmid}

HeLa cells were cultured in a humidified atmosphere of $5 \% \mathrm{CO}_{2}$ in air at $37{ }^{\circ} \mathrm{C}$ in DMEM medium supplemented with FBS 10\% (GIBCO). 
Fisher rat thyroid (FRT) cells were cultured in 6-well plates with Coon's modified F12 medium and the addition of fetal bovine serum (10\% FBS), $2.68 \mathrm{~g} / \mathrm{L}$ sodium bicarbonate, $2 \mathrm{mM}$ glutamine, $100 \mathrm{U} / \mathrm{mL}$ penicillin, and $100 \mu \mathrm{g} / \mathrm{mL}$ streptomycin. Antibiotics were removed before the addition of TRIDs.

\subsection{Measurement of Luciferase Activity by Luminescence}

HeLa cells were transfected with Fluc-WT and Fluc-opal plasmids combined with lipofectamine 2000 (Invitrogen) in a 6-well plate at a density of $2 \times 10^{5} / \mathrm{ml}$ Cells were incubated for $24 \mathrm{~h}$, then PTC124 and the three selected molecules $(12 \mu \mathrm{M})$ were added for an additional $24 \mathrm{~h}$. After washing with PBS, cells were incubated with the detection mix Steady-Glo luciferase reagent (Promega, Madison, WI, USA). Then, $200 \mu \mathrm{L}$ of cell suspension was plated in triplicate in a 96-well plate. Luciferase activity was finally measured on a luminometer (Promega, Madison, WI, USA).

\subsection{Immunofluorescence Microscopy}

Cells grown on rounded glass coverslips were fixed with methanol for $2 \mathrm{~min}$. The wheat germ agglutinin (WGA) Alexa 594 (Life Technologies, Carlsbad, CA, USA) was used to stain the cell membrane and Golgi apparatus, while nuclei were visualized with DAPI. CFTR was detected by incubation with a mouse monoclonal antibody (ab570-mouse 1:500) overnight at $4{ }^{\circ} \mathrm{C}$, followed by a goat polyclonal to mouse Alexa-Fluor-488 (Abcam, 1:1000, Cambridge, UK) secondary antibody for $1 \mathrm{~h}$ at $37^{\circ} \mathrm{C}$. Cells were observed under a Zeiss Axioskop microscope (Oberkochen, Baden-Württemberg, Germany) equipped for fluorescence.

\subsection{Western Blotting}

Proteins $(30 \mu \mathrm{g})$ separated by 10\% SDS-PAGE and 3-8\% SDS-PAGE $(0.1 \%$ SDS) were transferred to Hybond-C nitrocellulose membranes (Life Technologies, Carlsbad, CA, USA by electroblotting. The blot was incubated with a mouse antibody anti-CFTR (Ab570 1:500), and HRP-conjugated anti-mouse (PIERCE, 1:5000). The target protein was detected by ECL reagents (Pierce -Thermo Fisher Scientific, Rodano, Italy)). Anti- $\beta$-tubulin antibody (mouse; Sigma-Aldrich, St. Louis, MO, USA, 1:10,000) confirmed the presence of an equal amount of proteins per well. Gel bands were quantified by ImageJ software.

\subsection{Microscope Fluorescence YFP Assay}

FRT cells expressing the halide-sensitive YFP and the human WT-CFTR, G542X-CFTR, or W1282X-CFTR cDNA were plated in a 96-well plate. After $24 \mathrm{~h}$, the cells were treated with the test compounds for $24 \mathrm{~h}$. Cells were then washed with phosphate-buffered saline (PBS: $137 \mathrm{mM}$ $\mathrm{NaCl}, 2.7 \mathrm{mM} \mathrm{KCl}, 8.1 \mathrm{mM} \mathrm{Na} \mathrm{HPO}_{4}, 1.5 \mathrm{mM} \mathrm{KH} \mathrm{PO}_{4}, 1 \mathrm{mM} \mathrm{CaCl}$, and $\left.0.5 \mathrm{mM} \mathrm{MgCl} 2\right)$ and prestimulated for $20 \mathrm{~min}$ with forskolin $(20 \mu \mathrm{M}$, acute dose; Selleckem, Houston, TX, USA) in a final volume of $60 \mu \mathrm{L}$. Microplates were then transferred to a fluorescence microscope (ZEISS, Oberkochen, Baden-Württemberg, Germany). YFP fluorescence images were captured by Axiocam ZEISS before $\left(t^{0}\right)$ and $30 \mathrm{~s}\left(\mathrm{t}^{30 \mathrm{~s}}\right)$ after the addition of $165 \mu \mathrm{L}(100 \mathrm{mM} /$ well $)$ of PBS-NaI, an iodide-containing solution. All images were captured with exposition time fixed at $800 \mathrm{~ms}$.

\subsection{Microplate Reader Fluorescence YFP Assay}

FRT cells expressing the human WT-CFTR, G542X-CFTR cDNA, or W1282X-CFTR cDNA, together with the halide-sensitive YFP, were plated in a-96 well plate and, after $24 \mathrm{~h}$, treated with the test compounds. After $24 \mathrm{~h}$ of treatment, the cells were washed with phosphate-buffered saline (PBS: $137 \mathrm{mM} \mathrm{NaCl}, 2.7 \mathrm{mM} \mathrm{KCl}, 8.1 \mathrm{mM} \mathrm{Na}_{2} \mathrm{HPO}_{4}, 1.5 \mathrm{mM} \mathrm{KH} \mathrm{PO}_{4}, 1 \mathrm{mM} \mathrm{CaCl}$, and $0.5 \mathrm{mM}$ $\left.\mathrm{MgCl}_{2}\right)$ and prestimulated for $20 \mathrm{~min}$ with forskolin $(20 \mu \mathrm{M}$, acute dose; Selleckem) in a final volume of $60 \mu \mathrm{L}$ in PBS1X. Microplates were then transferred to a microplate reader to measure the fluorescence 
before $\left(\mathrm{t}^{0}\right)$ and $30 \mathrm{~s}\left(\mathrm{t}^{30 \mathrm{~s}}\right)$ after the addition of $165 \mu \mathrm{L}(100 \mathrm{mM} /$ well $)$ of PBS-NaI, an iodide-containing solution. The assay was performed in triplicate.

\subsection{Data Analysis}

All data are expressed as mean values \pm standard error of the mean. Statistical analysis was performed by Student's $t$-test and one-way ANOVA followed by Dunnet's posthoc test, when appropriate (by GraphPad Prism Software version 8.0.0 for Windows, San Diego, CA, USA). A probability value $(p)$ of less than 0.05 was regarded as significant and indicated in relevant graphs as one symbol $\left(^{*}\right)$ for $p<0.05$, two symbols $\left(^{* *}\right)$ for $p<0.01$, and three symbols $\left(^{* * *}\right)$ for $p<0.001$.

\section{Conclusions}

The readthrough approach to nonsense is worth being considered as therapy for genetic disorders caused by the presence of a PTC in the mRNA.

The identification of molecules displaying readthrough activity of the PTCs is a very hot topic in the challenge posed by nonsense mutations to find a valuable therapeutic treatment for the second major cause of $\mathrm{CF}$.

Some pitfalls in the readthrough process, when known, can be faced. One issue is that the NMD pathway may lower the efficacy of TRIDs and, in this case, NMD inhibition associated with TRID treatment can improve the amount of rescued protein.

In some cases, TRIDs can revert a nonsense mutation to a missense mutation, thus producing a nonfunctional protein. In these situations, associating appropriate drugs to correct the missense mutation effect should be considered as a possible solution. For this reason, in the search for new TRIDs, besides quantitatively testing the amount of protein expressed by the induced readthrough, it is of paramount importance to also test the functional recovery.

In this project, we designed, synthesized, and biologically tested three new 1,2,4-oxadiazoles TRIDs showing a high readthrough activity with the production of a full length, and most importantly, functional CFTR protein from mutant CFTR cDNAs carrying opal stop mutations.

All three molecules evidenced higher activity than ataluren when tested at $12 \mu \mathrm{M}$, the concentration at which ataluren shows its best response, and even higher activity at $24 \mu \mathrm{M}$, as evidenced in the dose-response analysis.

These molecules show high readthrough efficacy, both in terms of protein recovery, as confirmed by WB analysis, and in terms of protein functionality. Following the treatment with the new compounds, we observed Fluc-opal luminescence recovery in HeLa cells. Then, by immunofluorescence, in FRT cells engineered with mutant CFTR cDNAs, we observed that CFTR rescued protein was properly localized on the cell membrane. Interestingly, by halide-sensitive YFP-based assay, we demonstrated that TRIDs restored the function of the CFTR channel encoded by PTCs harboring mRNAs. Moreover, the three molecules showed lower cytotoxic effects when compared to ataluren and the previously reported NV2445.

Notwithstanding their limits, pharmacological approaches to nonsense suppression are a fascinating field in view of a wider application to different genetic diseases whose common denominator is a nonsense mutation. In this context, the various processes involved in the readthrough pathway require future research on synergistic effects of NMD inhibition, readthrough induction, and postreadthrough correction.

\section{Patents}

I. Pibiri, A. Pace, M. Tutone, L. Lentini, R. Melfi, A. Di Leonardo, Oxadiazole Derivatives For The Treatment Of Genetic Diseases Due To Nonsense Mutations, PCT Int. Appl. (2019), WO 2019/101709 A1 20190531.

Supplementary Materials: The following are available online at http://www.mdpi.com/1422-0067/21/17/6420/s1. 
Author Contributions: The manuscript was written through the contributions of all authors. Conceptualization, I.P. and L.L.; Data curation, I.P., R.M., M.T. and L.L.; Formal analysis, R.M. and M.T.; Funding acquisition, I.P. and L.L.; Investigation, I.P. and R.M.; Methodology, I.P., A.D.L., A.P. and L.L.; Project administration, I.P. and L.L.; Software, M.T.; Supervision, I.P. and L.L.; Validation, I.P. and A.P.; Visualization, M.T., A.D.L. and A.P.; Writing-original draft, I.P., R.M. and L.L.; Writing—review \& editing, I.P. and L.L. All authors have read and agree to the published version of the manuscript.

Funding: This research was funded by the Italian Cystic Fibrosis Research Foundation, grant FFC\#3/2017, with the contribution of Delegazione di Palermo, Delegazione di Vittoria (Ragusa) e Siracusa, and Delegazione FFC di Catania Mascalucia to Laura Lentini and Ivana Pibiri.

Acknowledgments: We thank J. Inglese, NIH Chemical Genomics Center, National Institutes of Health, Bethesda, for providing us with the FLuc190UGA plasmid, Louis Galietta (TIGEM, Napoli, Italy) and Dott.ssa Loretta Ferrera (Gaslini Hospital, Genova, Italy) for kindly providing us with the FRT cells and the pTracer CFTRWT vector.

Conflicts of Interest: The authors declare no conflict of interest.

\section{Abbreviations}

$\begin{array}{ll}\text { TRID } & \text { Translational Readthrough Inducing Drugs } \\ \text { CFTR } & \text { Cystic Fibrosis Transmembrane Regulator } \\ \text { CF } & \text { Cystic Fibrosis } \\ \text { Ns } & \text { Nonsense } \\ \text { NMD } & \text { Nonsense Mediated Decay } \\ \text { PTC } & \text { Premature Termination Codon } \\ \text { YFP } & \text { Yellow Fluorescent Protein } \\ \text { DMD } & \text { Duchenne Muscular Dystrophy } \\ \text { FRT } & \text { Fischer Rat Thyroid } \\ \text { DAPI } & 4^{\prime}, 6 \text {-diamidino-2-phenylindole } \\ \text { WB } & \text { Western Blot }\end{array}$

\section{References}

1. Zhang, Z.; Miteva, M.A.; Wang, L.; Alexov, E. Analyzing Effects of Naturally Occurring Missense Mutations. Comput. Math. Methods Med. 2012, 2012, 805827. [CrossRef]

2. Chang, Y.-F.; Saadi Imam, J.; Wilkinson, M.F. The Nonsense-Mediated Decay RNA Surveillance Pathway. Annu. Rev. Biochem. 2007, 76, 51-74. [CrossRef]

3. Dabrowski, M.; Bukowy-Bieryllo, Z.; Zietkiewicz, E. Translational readthrough potential of natural termination codons in eucaryotes-The impact of RNA sequence. RNA Biol. 2015, 12, 950-958. [CrossRef]

4. Kellermayer, R. Translational readthrough induction of pathogenic nonsense mutations. Eur. J. Med. Genet. 2006, 49, 445-450. [CrossRef] [PubMed]

5. Blanchet, S.; Cornu, D.; Argentini, M.; Namy, O. New insights into the incorporation of natural suppressor tRNAs at stop codons in Saccharomyces cerevisiae. Nucleic Acids Res. 2014, 42, 10061-10072. [CrossRef] [PubMed]

6. Blanchet, S.; Cornu, D.; Hatina, I.; Grosjeana, H.; Bertina, P.; Namy, O. Deciphering the reading of the genetic code by near-cognate tRNA. Proc. Natl. Acad. Sci. USA 2018, 115, 3018-3023. [CrossRef] [PubMed]

7. Roy, B.; Friesen, W.J.; Tomizawa, Y.; Leszyk, J.D.; Zhuo, J.; Johnson, B.; Dakka, J.; Trotta, C.R.; Xue, X.; Mutyam, V.; et al. Ataluren stimulates ribosomal selection of near-cognate tRNAs to promote nonsense suppression. Proc. Natl. Acad. Sci. USA 2016, 113, 12508-12513. [CrossRef] [PubMed]

8. Dabrowski, M.; Bukowy-Bieryllo, Z.; Zietkiewicz, E. Advances in therapeutic use of a drug stimulated translational readthrough of premature termination codons. Mol. Med. 2018, 24, 25. [CrossRef]

9. Tutone, M.; Pibiri, I.; Lentini, L.; Pace, A.; Almerico, A.M. Deciphering the Nonsense Readthrough Mechanism of Action of Ataluren: An in Silico Compared Study. ACS Med. Chem. Lett. 2019, 10, 522-527. [CrossRef]

10. Lentini, L.; Melfi, R.; Cancemi, P.; Pibiri, I.; Di Leonardo, A. Caffeine boosts Ataluren's readthrough activity. Heliyon 2019, 5, e01963. [CrossRef] 
11. Linde, L.; Boelz, S.; Nissim-Rafinia, M.; Oren, Y.S.; Wilschanski, M.; Yaacov, Y.; Virgilis, D.; Neu-Yilik, G.; Kulozik, A.E.; Kerem, E.; et al. Nonsense-mediated mRNA decay affects nonsense transcript levels and governs response of cystic fibrosis patients to gentamicin. J. Clin. Investig. 2007, 117, 683-692. [CrossRef] [PubMed]

12. Keeling, K.M.; Wang, D.; Dai, Y.; Murugesan, S.; Chenna, B.; Clark, J.; Belakhov, V.; Kandasamy, J.; Velu, S.E.; Baasov, T.; et al. Attenuation of nonsense-mediated mRNA decay enhances in vivo nonsense suppression. PLOS ONE 2013, 8, e60478. [CrossRef] [PubMed]

13. Usuki, F.; Yamashita, A.; Higuchi, I.; Ohnishi, T.; Shiraishi, T.; Osame, M.; Ohno, S. Inhibition of nonsense-mediated mRNA decay rescues the phenotype in Ullrich's disease. Ann. Neurol. 2004, 55, 740-744. [CrossRef] [PubMed]

14. Usuki, F.; Yamashita, A.; Kashima, I.; Higuchi, I.; Osame, M.; Ohno, S. Specific inhibition of nonsense-mediated mRNA decay components, SMG-1 or UPF1, rescues the phenotype of Ullrich disease fibroblasts. Mol. Ther. 2006, 14, 351-360. [CrossRef]

15. Branchini, A.; Ferrarese, M.; Campioni, M.; Castaman, G.; Mari, R.; Bernardi, F.; Pinotti, M. Specific factor IX mRNA and protein features favor drug-induced readthrough over recurrent nonsense mutations. Blood 2019, 129, 2303-2307. [CrossRef]

16. Lombardi, S.; Ferrarese, M.; Marchi, S.; Pinton, P.; Pinotti, M.; Bernardi, F.; Branchini, A. Translational readthrough of GLA nonsense mutations suggests dominant-negative effects exerted by the interaction of wild-type and missense variants. RNA Biol. 2020, 17, 254-263. [CrossRef]

17. Peltz, S.W.; Morsy, M.; Welch, E.M.; Jacobson, A. Ataluren as an Agent for Therapeutic Nonsense Suppression. Annu. Rev. Med. 2013, 64, 407-425. [CrossRef]

18. Ardicli, D.; Haliloglu, G.; Alikasifoglu, M.; Topaloglu, H. Diagnostic Pathway to Nonsense Mutation Dystrophinopathy: A Tertiary-Center, Retrospective Experience. Neuropediatrics 2019, 50, 41-45. [CrossRef]

19. Sossi, V.; Giuli, A.; Vitali, T.; Tiziano, F.; Mirabella, M.; Antonelli, A.; Neri, G.; Brahe, C. Premature termination mutations in exon 3 of the SMN1 gene are associated with exon skipping and a relatively mild SMA phenotype. Eur. J. Hum. Genet. 2001, 9, 113-120. [CrossRef]

20. Li, N.; Wang, L.; Sun, X.; Lu, Z.; Suo, X.; Li, J.; Peng, J.; Peng, R. A novel mutation in VRK1 associated with distal spinal muscular atrophy. J. Hum. Genet. 2019, 64, 215-219. [CrossRef]

21. Li, K.; Turner, A.N.; Chen, M.; Brosius, S.N.; Schoeb, T.R.; Messiaen, L.M.; Bedwell, D.M.; Zinn, K.R.; Anastasaki, C.; Gutmann, D.H.; et al. Mice with missense and nonsense NF1 mutations display divergent phenotypes compared with human neurofibromatosis type I. Dis. Model. Mech. 2016, 9, 759-767. [CrossRef] [PubMed]

22. Xie, Y.A.; Lee, W.; Cai, C.; Gambin, T.; Nõupuu, K.; Sujirakul, T.; Ayuso, C.; Jhangiani, S.; Muzny, D.; Boerwinkle, E.; et al. New syndrome with retinitis pigmentosa is caused by nonsense mutations in retinol dehydrogenase RDH11. Hum. Mol. Genet. 2014, 23, 5774-5780. [CrossRef] [PubMed]

23. Kiser, K.; Webb-Jones, K.D.; Bowne, S.J.; Sullivan, S.L.; Daiger, S.P.; Birch, D.G. Time Course of Disease Progression of PRPF31-mediated Retinitis Pigmentosa. Am. J. Ophthalmol. 2019, 200, 76-84. [CrossRef]

24. Samanta, A.; Stingl, K.; Kohl, S.; Ries, J.; Linnert, J.; Nagel-Wolfrum, K. Ataluren for the Treatment of Usher Syndrome 2A Caused by Nonsense Mutations Int. J. Mol. Sci. 2019, 20, 6274. [CrossRef] [PubMed]

25. Banning, A.; Schiff, M.; Tikkanen, R. Amlexanox provides a potential therapy for nonsense mutations in the lysosomal storage disorder Aspartylglucosaminuria. Biochim. Biophys. Acta Mol. Basis Dis. 2018, 1864, 668-675. [CrossRef]

26. Keeling, K.M. Nonsense Suppression as an Approach to Treat Lysosomal Storage Diseases. Diseases 2016, 4, 32. [CrossRef]

27. Chernushyn, S.; Gulkovskyi, R.; Livshits, L. Novel Mutation in the MECP2 Gene Identified in a Group of Rett Syndrome Patients from Ukraine. Cytol. Genet. 2018, 52, 294-298. [CrossRef]

28. Bezzerri, V.; Bardelli, D.; Morini, J.; Vella, A.; Cesaro, S.; Sorio, C.; Biondi, A.; Danesino, C.; Farruggia, P.; Assael, B.M.; et al. Ataluren-driven restoration of Shwachman-Bodian-Diamond syndrome protein function in Shwachman-Diamond syndrome bone marrow cells. Am. J. Hematol. 2017, 93, 527-536. [CrossRef]

29. Bezzerri, V.; Api, M.; Allegri, M.; Fabrizzi, B.; Corey, S.J.; Cipolli, M. Nonsense Suppression Therapy: New Hypothesis for the Treatment of Inherited Bone Marrow Failure Syndromes. Int. J. Mol. Sci. 2020, 21, 4672. [CrossRef] 
30. Goldmann, T.; Overlack, N.; Wolfrum, U.; Nagel-Wolfrum, K. PTC124-Mediated Translational Readthrough of a Nonsense Mutation Causing Usher Syndrome Type 1C. Hum. Gene Ther. 2011, 22, 537-547. [CrossRef]

31. Mirtajani, S.B.; Farnia, P.; Hassanzad, M.; Ghanavi, J.; Farnia, P.; Velayati, A.A. Geographical distribution of cystic fibrosis; The past 70 years of data analysis. Biomed. Biotechnol. Res. J. 2017, 1, 105-112.

32. Farinha, C.M.; Canato, S. From the endoplasmic reticulum to the plasma membrane: Mechanisms of CFTR folding and trafficking Cell. Mol. Life Sci. 2017, 74, 39-55. [CrossRef] [PubMed]

33. Rowe, S.M.; Miller, S.; Sorscher, E.J. Cystic fibrosis. N. Engl. J. Med. 2005, 352, 1992-2001. [CrossRef] [PubMed]

34. Son, J.-H.; Zhu, J.S.; Phuan, P.-W.; Cil, O.; Teuthorn, A.P.; Ku, C.K.; Lee, S.; Verkman, A.S.; Kurth, M.J. High-Potency Phenylquinoxalinone Cystic Fibrosis Transmembrane Conductance Regulator (CFTR) Activators. J. Med. Chem. 2017, 60, 2401-2410. [CrossRef]

35. Ye, L.; Hu, B.; El-Badri, F.; Hudson, B.M.; Phuan, P.-W.; Verkman, A.S.; Tantillo, D.J.; Kurth, M.J. $\triangle \mathrm{f} 508-C F T R$ correctors: Synthesis and evaluation of thiazole-tethered imidazolones, oxazoles, oxadiazoles, and thiadiazoles. Bioorg. Med. Chem. Lett. 2014, 24, 5840-5844. [CrossRef]

36. Coffman, K.C.; Nguyen, H.H.; Phuan, P.-W.; Hudson, B.M.; Yu, G.J.; Bagdasarian, A.L.; Montgomery, D.; Lodewyk, M.W.; Yang, B.; Yoo, C.L.; et al. Constrained bithiazoles: Small molecule correctors of defective ff508-CFTR protein trafficking. J. Med. Chem. 2014, 57, 6729-6738. [CrossRef]

37. Ponzano, S.; Nigrelli, G.; Fregonese, L.; Eichler, I.; Bertozzi, F.; Bandiera, T.; Galietta, L.J.V.; Papaluca, M. A European regulatory perspective on cystic fibrosis: Current treatments, trends in drug development and translational challenges for CFTR modulators. Eur. Resp. Rev. 2018, 27, 170124-170134. [CrossRef]

38. Liessi, N.; Cichero, E.; Pesce, E.; Arkel, M.; Salis, A.; Tomati, V.; Paccagnella, M.; Damonte, G.; Tasso, B.; Galietta, L.J.V.; et al. Synthesis and biological evaluation of novel thiazole-VX-809 hybrid derivatives as F508del correctors by QSAR-based filtering tools. Eur. J. Med. Chem. 2018, 144, 179-200. [CrossRef]

39. Fanen, P.; Wohlhuter-Haddad, A.; Hinzpeter, A. Genetics of cystic fibrosis: CFTR mutation classifications toward genotype-based CF therapies: Genetics of CF. Int. J. Biochem. Cell Biol. 2014, 52, 94-102. [CrossRef]

40. Burke, J.F.; Mogg, A.E. Suppression of a nonsense mutation in mammalian cells in vivo by the aminoglycoside antibiotics G-418 and paromomycin. Nucleic Acids Res. 1985, 13, 6265-6272. [CrossRef]

41. Manuvakhova, M.; Keeling, K.; Bedwell, D.M. Aminoglycoside antibiotics mediate context-dependent suppression of termination codons in a mammalian translation system. RNA 2000, 6, 1044-1055. [CrossRef] [PubMed]

42. Roy, B.; Leszyk, J.D.; Mangus, D.A.; Jacobson, A. Nonsense suppression by near-cognate tRNAs employs alternative base pairing at codon positions 1 and 3. Proc. Natl. Acad. Sci. USA 2015, 112, 3038-3043. [CrossRef] [PubMed]

43. Prayle, A.; Smyth, A.R. Aminoglycoside use in cystic fibrosis: Therapeutic strategies and toxicity. Curr. Opin. Pulm. Med. 2010, 16, 604-610. [CrossRef] [PubMed]

44. Leubitz, A.; Frydman-Marom, A.; Sharpe, N.; van Duzer, J.; Campbell, K.C.M.; Vanhoutte, F. Safety, Tolerability, and Pharmacokinetics of Single Ascending Doses of ELX-02, a Potential Treatment for Genetic Disorders Caused by Nonsense Mutations, in Healthy Volunteers. Clin. Pharm. Drug Dev. 2019, 8, 984-994. [CrossRef]

45. Arakawa, M.; Shiozuka, M.; Nakayama, Y.; Hara, T.; Hamada, M.; Kondo, S.; Ikeda, D.; Takahashi, Y.; Sawa, R.; Nonomura, Y.; et al. Negamycin Restores Dystrophin Expression in Skeletal and Cardiac Muscles of mdx Mice. J. Biochem. 2003, 134, 751-758. [CrossRef]

46. Friesen, W.J.; Trotta, C.R.; Tomizawa, Y.; Zhuo, J.; Johnson, B.; Sierra, J.; Roy, B.; Weetall, M.; Hedrick, J.; Sheedy, J.; et al. The nucleoside analog clitocine is a potent and efficacious readthrough agent. RNA 2017, 23, 567-577.

47. Welch, E.M.; Barton, E.R.; Zhuo, J.; Tomizawa, Y.; Friesen, W.J.; Trifillis, P.; Paushkin, S.; Patel, M.; Trotta, C.R.; Hwang, S.; et al. PTC124 targets genetic disorders caused by nonsense mutations. Nature 2007, 447, 87-91. [CrossRef]

48. Kerem, E.; Hirawat, S.; Armoni, S.; Yaakov, Y.; Shoseyov, D.; Cohen, M.; Nissim-Rafinia, M.; Blau, H.; Rivlin, J.; Aviram, M.; et al. Effectiveness of PTC124 treatment of cystic fibrosis caused by nonsense mutations: A prospective phase II trial. Lancet 2008, 372, 719-727. [CrossRef] 
49. Kerem, E.; Konstan, M.W.; De Boeck, K.; Accurso, F.J.; Sermet-Gaudelus, I.; Wilschanski, M.; Elborn, J.S.; Melotti, P.; Bronsveld, I.; Fajac, I.; et al. A randomized placebo-controlled trial of Ataluren for the treatment of nonsense mutation cystic fibrosis. Lancet Respir. Med. 2014, 2, 539-547. [CrossRef]

50. Aslam, A.A.; Higgins, C.; Sinha, I.P.; Southern, K.W. Ataluren and similar compounds (specific therapies for premature termination codon class I mutations) for cystic fibrosis. Paediatr. Respir. Rev. 2017, 24, 32-34.

51. Lentini, L.; Melfi, R.; Di Leonardo, A.; Spinello, A.; Barone, G.; Pace, A.; Palumbo Piccionello, A.; Pibiri, I. Towards a rationale for the PTC124 (Ataluren) promoted read-through of premature stop codons: A computational approach and GFP- reporter cell-based assay. Mol. Pharm. 2014, 11, 653-664. [CrossRef] [PubMed]

52. Pibiri, I.; Lentini, L.; Tutone, M.; Melfi, R.; Pace, A.; Di Leonardo, A. Exploring the Readthrough of Nonsense Mutations by Non-Acidic Ataluren Analogues Selected by Ligand-Based Virtual Screening. Eur. J. Med. Chem. 2016, 122, 429-435. [CrossRef] [PubMed]

53. Pibiri, I.; Lentini, L.; Melfi, R.; Gallucci, G.; Pace, A.; Spinello, A.; Barone, G.; Di Leonardo, A. Enhancement of Premature Stop Codon Readthrough in the CFTR Gene by Ataluren (PTC124) Derivatives. Eur. J. Med. Chem. 2015, 101, 236-244. [CrossRef] [PubMed]

54. Pibiri, I.; Lentini, L.; Melfi, R.; Tutone, M.; Baldassano, S.; Ricco Galluzzo, P.; Di Leonardo, A.; Pace, A. Rescuing the CFTR Protein Function: Introducing 1,3,4-Oxadiazoles as Translational Readthrough Inducing Drugs. Eur. J. Med. Chem. 2018, 159, 126-142. [CrossRef]

55. Campofelice, A.; Lentini, L.; Di Leonardo, A.; Melfi, R.; Tutone, M.; Pace, A.; Pibiri, I. Strategies against Nonsense: Oxadiazoles as Translational Readthrough-Inducing Drugs (TRIDs). Int. J. Mol. Sci. 2019, 20, 3329. [CrossRef]

56. Pace, A.; Buscemi, S.; Palumbo Piccionello, A.; Pibiri, I. Recent Advances in the Chemistry of 1,2,4-Oxadiazoles. Adv. Heterocycl. Chem. 2016, 116, 85-136.

57. Rubino, S.; Pibiri, I.; Minacori, C.; Alduina, R.; Di Stefano, V.; Orecchio, S.; Buscemi, S.; Girasolo, M.A.; Tesoriere, L.; Attanzio, A. Synthesis, structural characterization, anti-proliferative and antimicrobial T activity of binuclear and mononuclear Pt(II) complexes with perfluoroalkyl- heterocyclic ligands. Inorg. Chim. Acta 2018, 483, 180-190. [CrossRef]

58. Rubino, S.; Pibiri, I.; Costantino, C.; Buscemi, S.; Girasolo, M.A.; Attanzio, A.; Tesoriere, L. Synthesis of platinum complexes with 2-(5-perfluoroalkyl-1,2,4-oxadiazol-3yl)-pyridine and 2-(3-perfluoroalkyl-1-methyl1,2,4-triazole-5yl)-pyridine ligands and their in vitro antitumor activity. J. Inorg. Biochem. 2016, 155, 92-100. [CrossRef]

59. Tutone, M.; Pecoraro, B.; Almerico, A.M. Investigation on Quantitative Structure-Activity Relationships of 1,3,4-Oxadiazole Derivatives as Potential Telomerase Inhibitors. Curr. Drug Discov. Technol. 2020, 17, 79-86. [CrossRef]

60. Vivona, N.; Ruccia, M.; Cusmano, G.; Marino, M.L.; Spinelli, D. The thermally degenerate mononuclear rearrangement of 3-acetylamino-5-methyl-1,2,4-oxadiazole. J. Heterocycl. Chem. 1975, 12, 1327-1328. [CrossRef]

61. Mugnoli, A.; Barone, G.; Buscemi, S.; Lanza, C.Z.; Pace, A.; Pani, M.; Spinelli, D. On the structure of 3-acetylamino-5-methyl-1,2,4-oxadiazole and on the fully degenerate rearrangements (FDR) of its anion: A stimulating comparison between the results of in-silicon chemistry and laboratory chemistry. J. Phys. Org. Chem. 2009, 22, 1086-1093. [CrossRef]

62. Pace, A.; Pibiri, I.; Palumbo Piccionello, A.; Buscemi, S.; Vivona, N.; Barone, G. Experimental and DFT Studies on Competitive Heterocyclic Rearrangements. Part 2:1 A One-Atom Side-Chain versus the Classic Three-Atom Side-Chain (Boulton-Katritzky) Ring Rearrangement of 3-Acylamino-1,2,4-oxadiazoles. J. Org. Chem. 2007, 72, 7656-7666. [CrossRef] [PubMed]

63. Auld, D.S.; Lovell, S.; Thorne, N.; Lea, W.A.; Maloney, D.J.; Shen, M.; Rai, G.; Battaile, K.P.; Thomas, C.J.; Simeonov, A.; et al. Molecular basis for the high-affinity binding and stabilization of firefly luciferase by PTC124. Proc. Natl. Acad. Sci. USA 2010, 107, 4878-4883. [CrossRef] [PubMed]

64. Sheppard, D.N.; Rich, D.P.; Ostedgaard, L.S.; Gregory, R.J.; Smith, A.E.; Welsh, M.J. Mutations in CFTR associated with mild-disease from Cl-channels with altered pore properties. Nature 1993, 362, 160-164. [CrossRef] [PubMed]

65. Pedemonte, N.; Tomati, V.; Sondo, E.; Galietta, L.J.V. Influence of cell background on pharmacological rescue of mutant CFTR. Am. J. Physiol. Cell Physiol. 2010, 298, 866-874. [CrossRef] 
66. Almerico, A.M.; Tutone, M.; Lauria, A. 3D-QSAR pharmacophore modeling and in silico screening of new Bcl-xl inhibitors. Eur. J. Med. Chem. 2010, 45, 4774-4782. [CrossRef]

67. Lauria, A.; Ippolito, M.; Fazzari, M.; Tutone, M.; Di Blasi, F.; Mingoia, F.; Almerico, A.M. IKK-b inhibitors: An analysis of drug-receptor interaction by using Molecular Docking and Pharmacophore 3D-QSAR approaches. J. Mol. Graph. Model. 2010, 29, 72-81. [CrossRef]

68. Almerico, A.M.; Tutone, M.; Lauria, A. Receptor-guided 3D-QSAR approach for the discovery of c-kit tyrosine kinase inhibitors. J. Mol. Model. 2012, 18, 2885-2895. [CrossRef]

69. Almerico, A.M.; Tutone, M.; Pantano, L.; Lauria, A. A3 adenosine receptor: Homology modeling and 3D-QSAR studies. J. Mol. Graph. Model. 2013, 42, 60-72. [CrossRef]

70. Perricone, U.; Wieder, M.; Seidel, T.; Langer, T.; Padova, A.; Almerico, A.M.; Tutone, M. A molecular dynamics-shared pharmacophore approach to boost early-enrichment virtual screening: A case study on peroxisome proliferator- activated receptora. Chem. Med. Chem. 2017, 12, 1399-1407. [CrossRef]

71. Branco, P.S.; Prabhakar, S.; Lobo, A.M.; Williams, D.J. Reactions of hydroxylamines with ethyl cyanoformate. preparation of aminonitrones and their synthetic applications. Tetrahedron 1992, 48, 6335-6360. [CrossRef]

72. Buscemi, S.; Pace, A.; Pibiri, I.; Vivona, N.; Caronna, T. Fluorinated heterocyclic compounds: An assay on the photochemistry of some fluorinated 1-oxa-2-azoles: An expedient route to fluorinated heterocycles. J. Fluor. Chem. 2004, 125, 165-173. [CrossRef]

73. Buscemi, S.; Pace, A.; Frenna, V.; Vivona, N. A generalized synthesis of 3-amino-5-aryl-, 3-amino-5polyfluorophenyl-, and 3-amino-5-alkyl-1,2,4-oxadiazoles through ring-degenerate rearrangements. Heterocycles 2002, 57, 811-823. [CrossRef]

74. Buscemi, S.; Pace, A.; Calabrese, R.; Vivona, N.; Metrangolo, P. Fluorinated heterocyclic compounds. A photochemical synthesis of 3-amino-5-perfluoroaryl-1,2,4-oxadiazoles. Tetrahedron 2001, 57, 5865-5871. [CrossRef]

(C) 2020 by the authors. Licensee MDPI, Basel, Switzerland. This article is an open access article distributed under the terms and conditions of the Creative Commons Attribution (CC BY) license (http://creativecommons.org/licenses/by/4.0/). 